\title{
The acute effect of exercise and nutrition on respiratory exchange ratio in women
}

\author{
Hailee L Wingfield, Abbie E Smith-Ryan", Malia N Melvin, Erica J Roelofs, Eric T Trexler \\ From The Eleventh International Society of Sports Nutrition (ISSN) Conference and Expo \\ Clearwater Beach, FL, USA. 20-21 June 2014
}

\section{Background}

Few studies exist evaluating metabolic responses to exercise and nutrition in women. Understanding sex-specific fuel differences may improve exercise prescription. PURPOSE: To examine the effect of exercise modality and pre-exercise carbohydrate $(\mathrm{CHO})$ or protein (PRO) ingestion on respiratory exchange ratio (RER) in women.

\section{Methods}

Twenty recreationally active women (Mean \pm SD; age $24.6 \pm 3.9$ yrs; height $164.4 \pm 6.6 \mathrm{~cm}$; weight $62.7 \pm 6.6 \mathrm{~kg}$; $\%$ fat $28.2 \pm 4.8 \%$ ) participated in this randomized crossover, double-blind study. After preliminary body composition and maximal strength testing, each participant completed six exercise sessions, consisting of three exercise modalities: aerobic endurance exercise (AEE; $30 \mathrm{~min}, 50 \%$ heart rate reserve), high-intensity interval running (HIIT; $10 \times 1 \mathrm{~min}$ on: $1 \mathrm{~min}$ off, $90 \%$ HRR), and high-intensity resistance training (HIRT; 6 exercises: 3 sets, 20 sec rest), and two acute nutritional interventions: 25 grams of $\mathrm{CHO}$ (maltodextrin) and PRO (whey protein isolate). Salivary samples were collected before each exercise session to determine estrogen. RER was analyzed via indirect calorimetry (Parvomedics TrueOne 2400) at: baseline, immediately post (IP), 30 minutes $(30 \mathrm{~min})$ post, and 60 minutes (60min) post-exercise. Subjects were seated and connected to the metabolic cart by a tube for 15 minutes at each time point. A mixed level model [modality (AEE vs. HIIT vs. HIRT) $\times$ treatment $(\mathrm{CHO}$ vs. PRO) $\times$ time (base vs. IP vs. $30 \mathrm{~min}$ vs. $60 \mathrm{~min}$ )] covaried for estrogen was used to evaluate RER. Consent to publish the results was obtained from all participants.

\section{Results}

Significant two-way interactions existed between modality and time $(\mathrm{p}<0.0001)$ and time and treatment $(\mathrm{p}<0.0001)$. Significant modality differences existed between HIIT and AEE $(p<0.0001)$, HIIT and HIRT $(p<0.0001)$, and AEE and HIRT $(p=0.0024)$. RER was significantly higher from HIIT than AEE and HIRT IP exercise $(\mathrm{p}<0.0001)$, and significantly lower from HIIT $30 \mathrm{~min}$ and $60 \mathrm{~min}$ post exercise $(\mathrm{p}<0.0001-\mathrm{p}=0.0020)$ than AEE. RER was significantly lower $30 \mathrm{~min}(\mathrm{p}=0.0169)$, but not $60 \mathrm{~min}$ post $(\mathrm{p}=0.3603)$ HIIT vs. HIRT. No significant differences existed between HIRT and AEE IP exercise ( $\mathrm{p}=0.3370)$; RER was significantly lower for HIRT than AEE 30min and $60 \mathrm{~min}$ post exercise $(\mathrm{p}=0.0004-0.0265)$. For time and treatment, RER was not significantly different between $\mathrm{CHO}$ and PRO IP exercise ( $\mathrm{p}=0.1150)$, but was significantly lower for PRO $30 \mathrm{~min}$ and $60 \mathrm{~min}$ post $(\mathrm{p}<0.0001$ $\mathrm{p}=0.0012$ ).

\section{Conclusions}

HIIT produced lower RER than AEE from 30 to $60 \mathrm{~min}$ post, and a lower RER than HIRT 30min post exercise. PRO ingestion prior to exercise decreased RER more than $\mathrm{CHO}$ ingestion beginning 30min post exercise. HIIT and HIRT were the most effective and time-efficient approaches at increasing fat utilization after exercise. Thirty minutes post exercise, fat utilization was increased from HIIT and HIRT compared to AEE. One hour after exercise, HIIT and HIRT were similar in fat utilization. PRO ingestion prior to exercise increased fat utilization more than $\mathrm{CHO}$. Combining HIIT and HIRT with pre-exercise PRO intake in women may lead to greater changes in weight and body composition due to decreased RER.

\footnotetext{
* Correspondence: abbsmith@email.unc.edu

Applied Physiology Laboratory, The University of North Carolina, Chapel Hill,
} North Carolina, USA 


\section{Acknowledgement}

This study was supported by the National Strength and Conditioning

Association Foundation. $\mathrm{CHO}$ and PRO were blinded and donated by

Dymatize Nutrition (Farmers Branch, TX, USA).

Published: 1 December 2014

doi:10.1186/1550-2783-11-S1-P5

Cite this article as: Wingfield et al:: The acute effect of exercise and

nutrition on respiratory exchange ratio in women. Journal of the

International Society of Sports Nutrition 2014 11(Suppl 1):P5.

Submit your next manuscript to BioMed Central and take full advantage of:

- Convenient online submission

- Thorough peer review

- No space constraints or color figure charges

- Immediate publication on acceptance

- Inclusion in PubMed, CAS, Scopus and Google Scholar

- Research which is freely available for redistribution

Submit your manuscript at www.biomedcentral.com/submit 